\title{
The Faunal Assemblage Inhabiting Seasonal Sea Ice in the Nearshore Arctic Ocean with Emphasis on Copepods
}

\author{
John C. Kern* and Andrew G. Carey, Jr. \\ School of Oceanography, Oregon State University, Corvallis, Oregon 97331, USA
}

\begin{abstract}
Large numbers of invertebrates were collected from the lower layer of seasonal ice in the nearshore Beaufort Sea, off the northern coast of Alaska in spring 1980 . Over $90 \%$ of the individuals found belonged to meiofaunal taxa. Although density within the ice was low compared to that typically found in sediments, it was comparable to the highest previous estimate from sea ice. Densities were lowest in samples taken in April and reached a maximum of around 50000 individuals $\mathrm{m}^{-2}$ in June. Nematodes were numerically dominant, but copepods and turbellarians were also abundant. Population structures of the 2 most numerous copepod species were examined and found to differ greatly. Cyclopina gracilis appeared to reproduce continuously during the study; both adults and young copepodites were always present. The population of Harpacticus sp. initially consisted only of juveniles; the growth of a single cohort was observed. Harpacticus sp. mated in the ice, but gravid females did not appear during the sampling period. Although the ephemeral seasonal sea ice habitat would seem to be very different from typical habitats of benthic copepods, these 2 species did not appear to possess any special strategies for living there.
\end{abstract}

\section{INTRODUCTION}

A unique habitat exists within the lower layers of polar and subpolar sea ice. The bottom ice layer has been described as being soft (Horner, 1976), or loose (Andriashev, 1968) in composition in contrast to the hard ice above. It has relatively constant temperatures $\left(-3^{\circ}\right.$ to $\left.0^{\circ} \mathrm{C}\right)$, sufficient nutrients to support algal growth, variable osmotic pressure, and a probable abundance of organic material (Meguro et al., 1967). Seasonal ice is generally 2.0 to $2.5 \mathrm{~m}$ thick, yet sufficient light of adequate quality passes through it to allow photosynthesis within the ice habitat (Maykut and Grenfell, 1975). Low densities of algae are present in Arctic nearshore ice from its formation in the fall until April, when a bloom occurs (Horner, 1977). By late May, the peak of the bloom, the algae have formed several centimeters of colored ice. Seasonal ice breaks up each year in late spring, so that organisms within the lower layers of this ice exist in an ephemeral habitat. Despite the temporary nature of the seasonal

\footnotetext{
- Present address: Department of Biology, University of South Florida, Tampa, Florida 33620, USA
}

ice environment, an abundance of life can be found there.

Invertebrates inhabit sea ice, but in contrast to the ice flora (reviewed by Horner, 1977), little is known about these organisms. Heliozoans, ciliates, nematodes, copepods, polychaetes, turbellarians, and amphipods have been collected from sea ice (Andriashev, 1968; Horner, 1976; Cross, 1982; Carey and Montagna, 1982), but quantitative estimates are rare. The type of information required to assess the importance of these organisms to polar marine ecosystems is not available.

This paper is the result of a study designed to obtain some basic information about sea ice fauna in the nearshore Arctic Ocean. The research undertaken had 2 main goals: (1) to obtain quantitative estimates of the fauna found at 1 site during the spring ice algal bloom (changes in density of major taxa and copepod species were monitored on short time intervals); (2) to investigate the population structures of some dominant species found in the ice during the sampling period. We were interested in learning if species in the ice had populations whose characteristics were similar to those of related species in benthic environments. 


\section{MATERIALS AND METHODS}

The study site was located on a large ice pan in the Beaufort Sea approximately $0.4 \mathrm{~km}$ north of Narwhal Island, Alaska (Fig. 1). A dive hole was cut through

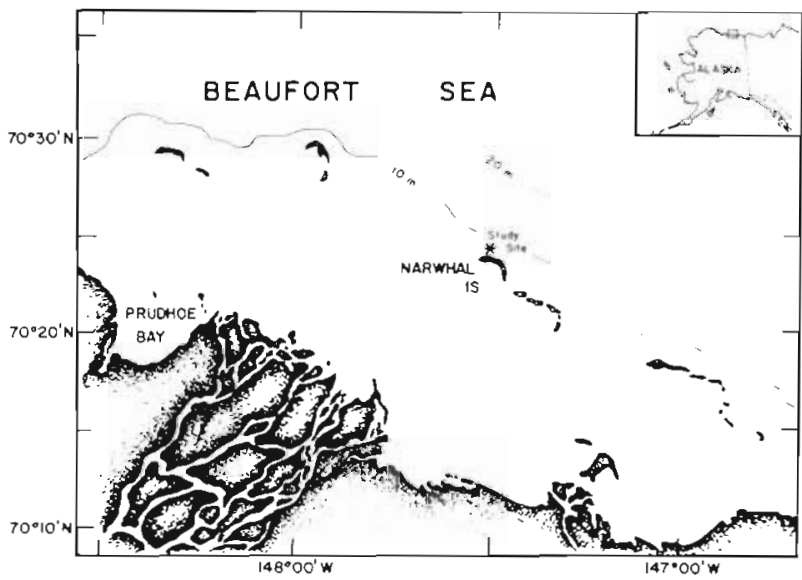

Fig. 1. Location of Narwhal Island study site

nearly $2 \mathrm{~m}$ of ice, over a muddy sand bottom lying $6.5 \mathrm{~m}$ below its lower surface. Samples were collected on 9 occasions from 14 April to 5 June 1980 by a diver using SCUBA, following the program outlined in Table 1. On the first and last collection dates, samples were obtained using an ice scraper (Carey, 1981). A corer of $10.5 \mathrm{~cm} \mathrm{i.} \mathrm{d.} \mathrm{was} \mathrm{employed} \mathrm{to} \mathrm{take} \mathrm{all} \mathrm{other} \mathrm{samples.}$ One end of each corer was covered with $64 \mu \mathrm{m}$ mesh. The open end was pushed into the lower surface of the ice until hard ice was reached. Cores were contained by sliding a spatula into the ice over the end of the corer, and then capped while underwater. All cores were collected within a $6 \mathrm{~m} \times 16 \mathrm{~m}$ area. Ice scraper samples were taken outside of this area, not farther than $40 \mathrm{~m}$ from the location of core samples.

Samples were placed into jars and transported to the lab where they were washed on a $64 \mu \mathrm{m}$ sieve. Animals were preserved in $10 \%$ buffered formalin and stained with rose bengal. Core samples were sorted and enu-

Table 1. Sampling program of 1980 spring ice study

\begin{tabular}{|clccc|}
\hline $\begin{array}{c}\text { Sampling } \\
\text { date }\end{array}$ & $\begin{array}{c}\text { Sampling } \\
\text { method }\end{array}$ & $\begin{array}{c}\text { \# of Sets } \\
\text { of cores }\end{array}$ & $\begin{array}{c}\text { \# of Cores } \\
\text { per set }\end{array}$ & $\begin{array}{c}\text { Total \# } \\
\text { cores }\end{array}$ \\
\hline $4 / 14$ & Ice scraper & - & - & - \\
$4 / 24$ & Corer & 3 & 3 & 9 \\
$5 / 5$ & Corer & 3 & 3 & 9 \\
$5 / 11$ & Corer & 3 & 2 & 6 \\
$5 / 15$ & Corer & 3 & 2 & 6 \\
$5 / 19$ & Corer & 3 & 2 & 6 \\
$5 / 26$ & Corer & 3 & 2 & 6 \\
$6 / 2$ & Corer & 3 & 2 & 6 \\
$6 / 5$ & Ice scraper & - & - & - \\
\end{tabular}

merated to major taxa under a dissecting microscope. Calanoid copepods, found infrequently in cores and always in low numbers, were not counted since it is unclear whether they were present in the corers prior to being inserted into the ice. Cyclopoid and harpacticoid copepods were identified to species. It was not possible in the time available to identify each copepodite to its stage. Instead, all undamaged individuals belonging to the 2 dominant copepod species, $C y c$ lopina gracilis and Harpacticus sp., were measured to the nearest $24 \mu \mathrm{m}$ using an ocular micrometer; total length, excluding the terminal setae, was measured. The presence of egg sacs and pre-copulatory clasping pairs was recorded for these species. One hundred $C$. gracilis, and 100 Harpacticus sp. were randomly chosen from ice scraper samples and measured, assuming that the ice scraper did not sample sizes or sexes of these species differently from the corers.

An analysis of variance with a nested design was used to test for changes over time in the density of major taxa and copepod species collected in cores. This design was required since on each date cores were taken in three randomly located sets (Table 1). Data were $\log ^{10}(x+1)$ transformed before the above test was performed to meet the assumption of ANOVA. We employed the Kolmogorov-Smirnov test (Tate and Clelland, 1957) to test whether the population size structure of the dominant copepod species changed over time. The size-frequency distribution at each sampling date was compared separately with the distribution of the preceding date, as well as the following date. Because the same data was tested several times, the chance of making an error by incorrectly rejecting the null hypothesis of no difference in population structure is increased. Therefore, to be conservative, the level of significance used to reject the null hypothesis was preset at 0.01 .

\section{RESULTS}

Nematodes, copepods, turbellarians, polychaetes, and amphipods were collected from the undersurface of the ice. The mean number of individuals collected per $100 \mathrm{~cm}^{2}$ for each group on all dates when corers were used is given in Table 2. Meiofaunal-sized organisms dominated the ice assemblage. Nematodes comprised $47.0 \%$ of the fauna collected throughout the study. Copepods and turbellarians made up $28.8 \%$ and $16.1 \%$ of the fauna, respectively. Polychaetes and amphipods were minor members of the ice fauna, together representing less than $10 \%$ of the total. Each group showed a significant change in abundance over time (Table 2). In general, the number of individuals within each taxon increased over time. Polychaetes 
Table 2. Mean abundance per $100 \mathrm{~cm}^{2}$ for major taxa collected on each sampling date. Results of nested ANOVA's are given. $\overline{\mathrm{X}}$ Mean, SD Standard deviation

\begin{tabular}{|c|c|c|c|c|c|c|c|c|}
\hline \multirow[b]{2}{*}{ Group } & \multicolumn{2}{|c|}{$4 / 24$} & \multicolumn{2}{|c|}{$5 / 5$} & \multicolumn{2}{|c|}{$5 / 11$} & \multicolumn{2}{|c|}{$5 / 15$} \\
\hline & $\bar{x}$ & SD & $\bar{x}$ & SD & $\bar{x}$ & SD & $\bar{x}$ & $\mathrm{SD}$ \\
\hline Nematoda & 3.59 & 1.95 & 9.23 & 10.51 & 34.84 & 33.92 & 62.36 & 17.74 \\
\hline Copepoda & 50.94 & 28.13 & 2721 & 13.62 & 24.63 & 10.06 & 57.74 & 27.59 \\
\hline Turbellaria & 2.96 & 2.53 & 2.06 & 2.15 & 4.82 & 3.45 & 6.16 & 4.42 \\
\hline Polychaeta & 51.07 & 65.30 & 14.63 & 19.51 & 1.35 & 0.87 & 9.62 & 13.12 \\
\hline \multirow[t]{2}{*}{ Amphipoda } & 2.82 & 2.09 & 2.18 & 2.34 & 2.31 & 1.63 & 6.54 & 4.04 \\
\hline & \multicolumn{2}{|c|}{$5 / 19$} & \multicolumn{2}{|c|}{$5 / 26$} & \multicolumn{2}{|c|}{$6 / 2$} & \multirow{2}{*}{\multicolumn{2}{|c|}{$\begin{array}{c}\text { Significant change } \\
\text { over time? (P) }\end{array}$}} \\
\hline Group & $\overline{\mathrm{X}}$ & SD & $\bar{X}$ & $\mathrm{SD}$ & $\bar{X}$ & $\mathrm{SD}$ & & \\
\hline Nematoda & 175.34 & 129.66 & 186.71 & 145.44 & 250.22 & 76.63 & \multicolumn{2}{|c|}{ Yes $(<.001)$} \\
\hline Copepoda & 109.71 & 56.63 & 125.11 & 81.39 & 69.87 & 36.51 & \multicolumn{2}{|c|}{$\operatorname{Yes}(<.02)$} \\
\hline Turbellaria & 52.93 & 14.57 & 26.56 & 9.49 & 151.67 & 22.65 & \multicolumn{2}{|c|}{ Yes $(<.001)$} \\
\hline Polychaeta & 7.89 & 6.42 & 18.10 & 21.86 & 8.08 & 5.89 & \multicolumn{2}{|c|}{ Yes $(<.005)$} \\
\hline Amphipoda & 9.24 & 7.04 & 11.93 & 7.47 & 2.51 & 1.99 & \multicolumn{2}{|c|}{ Yes $(<.004)$} \\
\hline
\end{tabular}

were an exception to this pattern, with their greatest density occurring in the earlier samples.

Seven species of cyclopoid and harpacticoid copepods were found within the ice. The mean number of individuals collected per $100 \mathrm{~cm}^{2}$ for each of the 5 dominant species, for each date on which cores were taken, is given in Table 3. Cyclopina gracilis, a cyclopoid, was the dominant species, making up $55.0 \%$ of the ice copepod fauna. Harpacticus sp. and Halectinosoma sp., 2 harpacticoids, comprised $23.0 \%$ and $19.8 \%$ of the copepods, respectively. The cyclopoid Oncaea sp. represented $1.5 \%$ of all copepods and Dactylopodia signata, a harpacticoid, less than $1 \%$. Two copepodites collected probably belonged to $C y c$ lopina schneideri. The $7^{\text {th }}$ species was represented by a single individual that was too young to be identified. Although there was a significant change in abundance over time for total copepod numbers, densities of 2 species, Halectinosoma sp. and D. signata, did not change significantly. The abundance of $C$. gracilis, Harpacticus sp., and Oncaea sp. did change significantly through the study (Table 3).

The size-frequency distribution of Harpactius sp. indicates that the population structure changed greatly during the course of the study (Fig. 2). Over $95 \%$ of the Harpacticus sp. individuals were measured. Initially the population was composed entirely of copepodites. By 15 May, however, a mode appeared at approximately $840 \mu \mathrm{m}$ that was composed of adult males and late copepodite females. This feature remained in later

Table 3. Mean abundance per $100 \mathrm{~cm}^{2}$ for the 5 dominant copepod species on each sampling date. Results of nested ANOVA's are given. $\overline{\mathrm{X}}$ Mean; SD Standard deviation

\begin{tabular}{|c|c|c|c|c|c|c|c|c|}
\hline \multirow[b]{2}{*}{ Species } & \multicolumn{2}{|c|}{$4 / 24$} & \multicolumn{2}{|c|}{$5 / 5$} & \multicolumn{2}{|c|}{$5 / 11$} & \multicolumn{2}{|c|}{$5 / 15$} \\
\hline & $\overline{\mathrm{X}}$ & $\mathrm{SD}$ & $\bar{x}$ & $\mathrm{SD}$ & $\bar{X}$ & $\mathrm{SD}$ & $\overline{\mathrm{X}}$ & $S D$ \\
\hline Cyclopina gracilis & 22.97 & 13.26 & 15.27 & 9.43 & 10.20 & 5.99 & 29.65 & 18.00 \\
\hline Harpacticus sp. & 10.39 & 7.96 & 6.55 & 4.65 & 5.58 & 3.13 & 11.74 & 6.83 \\
\hline Halectinosoma sp. & 15.52 & 11.41 & 4.11 & 2.45 & 8.08 & 2.92 & 9.82 & 7.37 \\
\hline Oncaea sp. & 0.51 & 0.84 & 0.25 & 0.51 & 0.38 & 0.60 & 2.51 & 2.36 \\
\hline \multirow[t]{2}{*}{ Dactylopodia signata } & 0.77 & 1.15 & 0.13 & 0.38 & 0.0 & - & 0.0 & - \\
\hline & \multicolumn{2}{|c|}{$5 / 19$} & \multicolumn{2}{|c|}{$5 / 26$} & \multicolumn{2}{|c|}{$6 / 2$} & \multirow{2}{*}{\multicolumn{2}{|c|}{$\begin{array}{c}\text { Significant change } \\
\text { over time? (P) }\end{array}$}} \\
\hline Species & $\bar{x}$ & SD & $\bar{X}$ & $\mathrm{SD}$ & $\bar{x}$ & SD & & \\
\hline Cyclopina gracilis & 60.78 & 34.24 & 76.99 & 40.73 & 34.65 & 27.27 & \multicolumn{2}{|c|}{ Yes $(<.02)$} \\
\hline Harpacticus sp. & 31.56 & 15.16 & 17.90 & 10.65 & 20.59 & 13.45 & \multicolumn{2}{|c|}{ Yes $(<.001)$} \\
\hline Halectinosoma sp. & 14.05 & 12.38 & 27.52 & 34.51 & 8.08 & 5.01 & \multicolumn{2}{|c|}{ No } \\
\hline Oncaea sp. & 1.35 & 0.87 & 0.38 & 0.95 & 1.73 & 2.71 & \multicolumn{2}{|c|}{ Yes $(<.05)$} \\
\hline Dactylopodia signata & 0.77 & 1.19 & 0.35 & 0.95 & 0.0 & - & \multicolumn{2}{|c|}{ No } \\
\hline
\end{tabular}




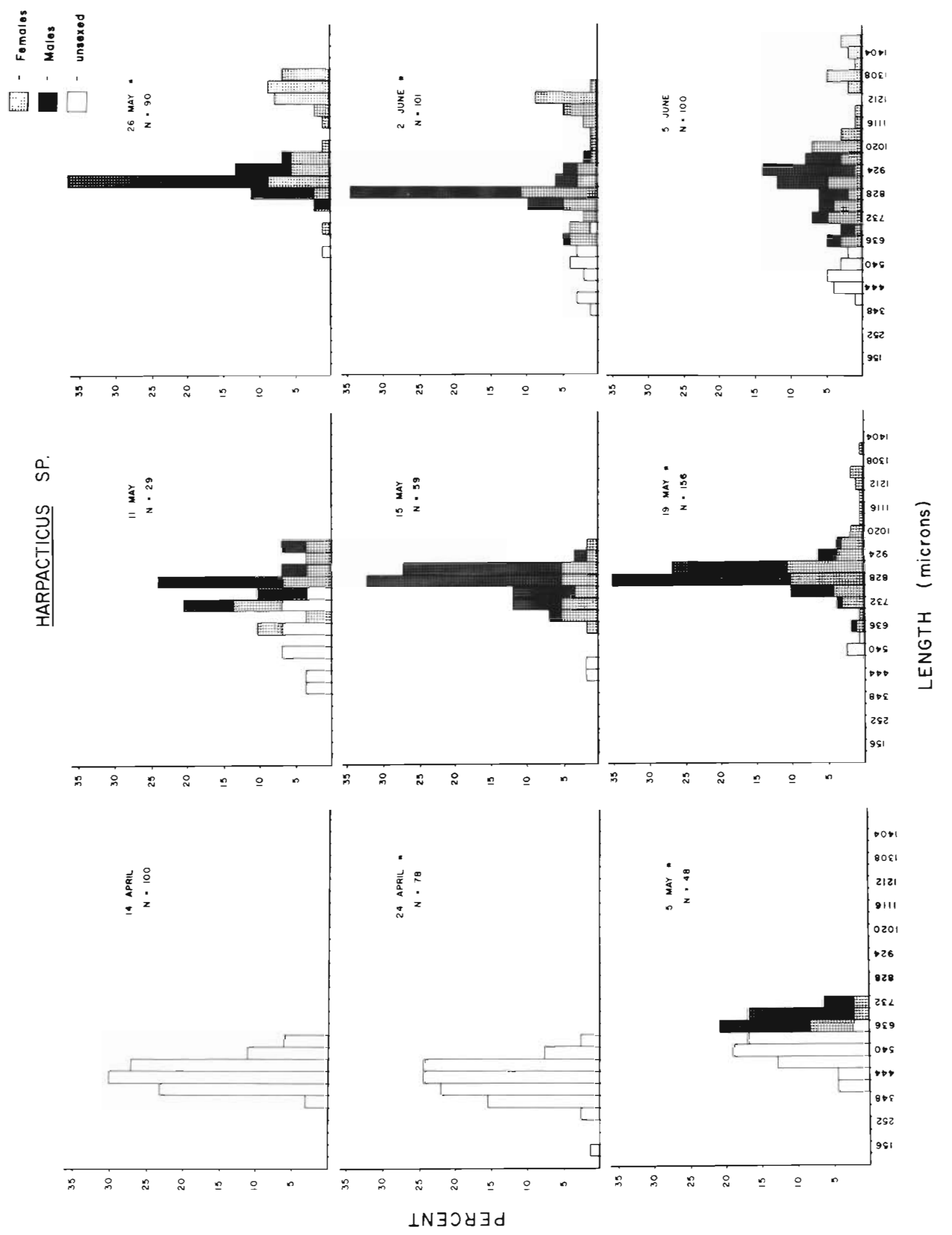


11

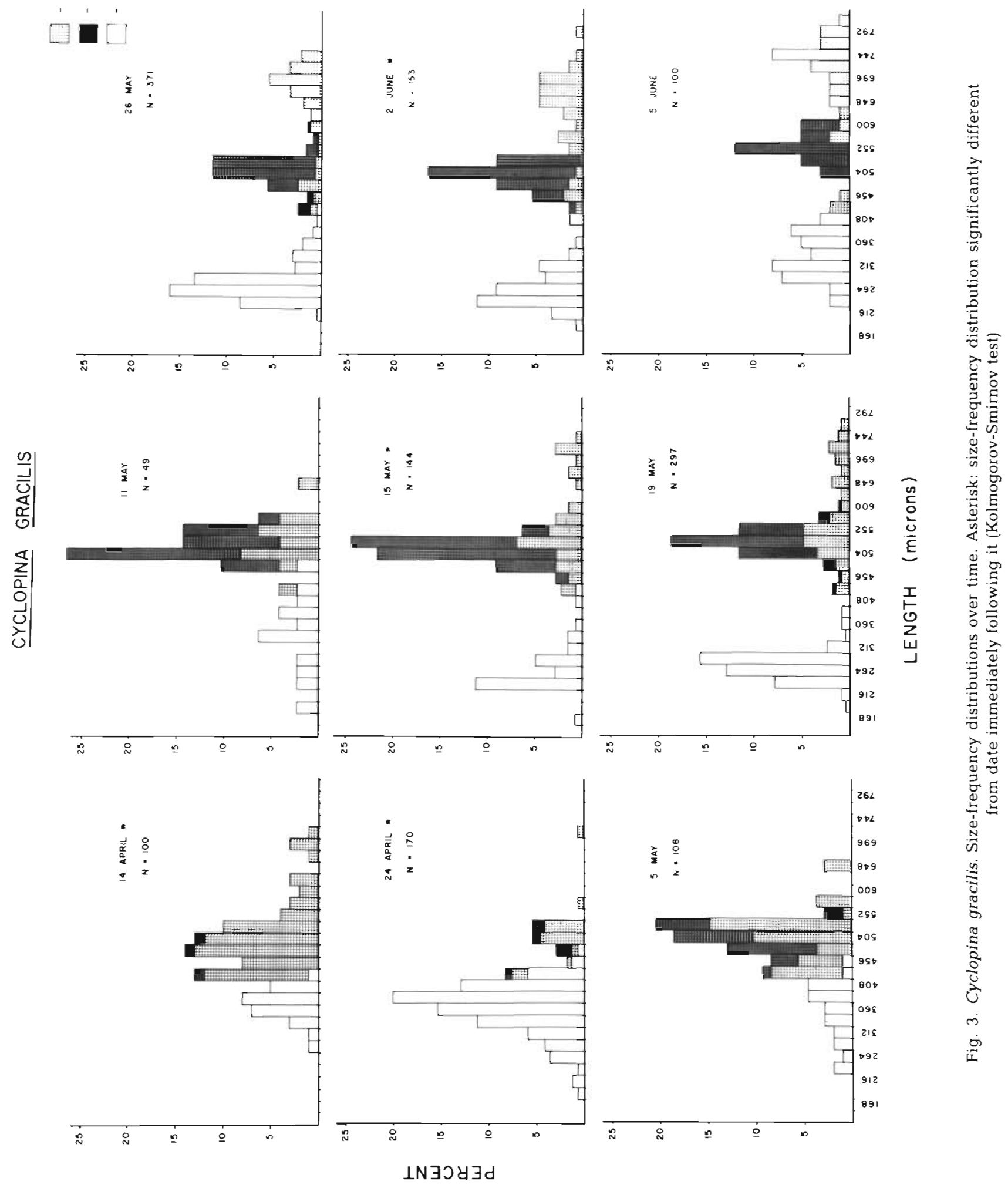


samples because the adult males had reached their maximum size. Females continued to grow, and a broad mode corresponding to adult females was seen beginning 19 May. Significant differences in population structure were indicated by the Kolmogorov-Smirnov test in the second and third comparisons (24 April vs. 5 May, 5 May vs. 11 May), and the last 3 (19 May vs. 26 May, 26 May vs. 2 June, 2 June vs. 5 June). Only 29 individuals were measured from 5 May; such sample size is inadequate to calculate the test statistic where the sample sizes are unequal (Tate and Clelland, 1957). To make comparisons between this date and the preceding and following sampling dates, the smaller sample size was used alone to determine the test statistic. No gravid Harpacticus sp. females were found in these samples, but clasping pairs were present on 26 May and 2 June.

The population structure of Cyclopina gracilis (Fig. 3) changed greatly during the study, but most of the changes occurred in the early samples. Over $92 \%$ of all individuals were measured. The Kolmagorov-Smirnov test indicates that significant changes in the sizefrequency distribution of the population occurred between sampling dates on 4 occasions (14 April vs. 24 April, 24 April vs. 5 May, 15 May vs. 19 May, 2 June vs. 5 June). In the cores taken 15 May, and in all following samples, 3 modes were evident in the size-frequency distributions. The first mode, centered at around $260 \mu \mathrm{m}$, was composed of young copepodites. The second, located at approximately $520 \mu \mathrm{m}$, was largely made up of adult males and late copepodite females. Adult females had a much greater size range than males, and had a broad peak centered near $700 \mu \mathrm{m}$. The presence of these 3 modes in the size-frequency distributions of C. gracilis from 15 May until the end of the sampling is an indication that the population structure was stable throughout this period. The changes detected by the Kolmogorov-Smimov test between population structures of 15 May and 19 May are due to differences in height of the peaks, not in their location. The size-structure of C. gracilis on 5 June had these 3 modes, but the modes were broader and had shifted to larger sizes relative to the prevoius dates. Gravid females were collected on 6 dates (24 April, 11 May, 15 May, 19 May, 26 May in cores, and 2 June in nonquantitative ice samples), but were never a large percentage of the adult female population.

\section{DISCUSSION}

The large numbers of animals found within the ice of the Beaufort Sea in 1980 is surprising. The ice fauna in Stefansson Sound, south of Narwhal Island and close to our study site, was examined in March and May 1979
(Carey and Montagna, 1982). Their density estimates were much smaller $\left(\bar{X}=6200\right.$ individuals $\mathrm{m}^{-2}$ ) even though they included calanoid copepods, crustacean nauplii, and rotifers in their count. Andriashev (1968) gives qualitative estimates of the density of ice fauna from the Antarctic Ocean, but his results also appear lower than we observed. Cross (1982) examined underice meiofauna at 5 stations in the Canadian Arctic in May 1979. Densities at 4 locations were low $(<2500$ individuals $\mathrm{m}^{-2}$ ), but were comparable to our highest estimates at his last station (approximately 50000 individuals $\mathrm{m}^{-2}$ ).

While the density of the ice fauna was greater than expected, it was only around 5 to $10 \%$ of typical benthic meiofaunal density (Coull and Bell, 1979). This may be due to the ephemeral nature of the seasonal ice habitat. Ice is only present in the nearshore Beaufort Sea from September or October until around June (Barnes and Reimnitz, 1975). Populations must colonize the lower layer of the ice each year. There is evidence, using artificial substrates suspended over the bottom, that some meiofaunal groups can rapidly develop large populations in abiotic sediments (Scheibel, 1974). Nematodes and copepods, the most numerous taxa in Beaufort Sea ice in 1980, were also the dominant groups colonizing the suspended substrates in Scheibel's study. This is not surprising since these 2 groups are typically the most abundant in normal sediments (McIntyre, 1969). At least some of the increase in Scheibel's study was due to continued immigration of animals after the sediments had initially been colonized. It is also possible that animals migrated to the ice from underlying sediments during our study. However, nematodes are not thought to be able to swim large distances (Scheibel, 1974), and continued movement of these organisms to the ice might depend on passive transport from the bottom by advection. Reproduction of copepods and nematodes was responsible for at least part of the increase in abundance observed in the ice. At least one gravid female of each of 3 ice copepods was collected, Cyclopina gracilis, Halectinosoma sp., and Dactylopdia signata. A few nematodes were examined, and gravid females were observed (E. W. Hogue, pers. comm.). Laboratory studies have shown that the time required for marine nematodes to complete one life cycle varies greatly, from less than 2 wk (Gerlach and Schrage, 1971) to almost 2 yr (Gerlach and Schrage, 1972). It may be possible that the rapid increase in abundance found for nematodes could largely be due to reproduction rather than passive transport if the species have short life cycles.

Population and life-history studies of marine benthic copepods have largly been restricted to harpacticoids living in sediments (e.g. Barnett, 1970; Lasker et al., 
1970; Jewett and Feder, 1977; Fleeger, 1979; Feller, 1980; Palmer, 1980; Soyer, 1980) or on algae (Hicks, 1977). These are permanent environments in contrast to the ephemeral sea ice habitat of the nearshore Beaufort Sea. These past studies have shown that copepods in permanent environments vary widely in population dynamics and life-history. Barnett (1970) investigated the life cycles of 2 congeneric species inhabiting the same mudflat and found that each species had a distinct life-history. Palmer (1980) observed that different life-history patterns were present in littoral and sublittoral populations of one harpacticoid species. There is no single life-history strategy utilized by benthic copepods, instead there is a range of strategies. The population structures of Cyclopina gracilis and Harpacticus sp. living in Beaufort Sea ice appear to fit range exhibited by benthic species studied in permanent environments.

It is evident that Harpacticus sp. and Cyclopina gracilis have different population characteristics (Fig. 2 and 3). C. gracilis appeared to reproduce continuously during our study. Gravid females were found on 6 of the 9 sampling dates. Since the number collected on any date tended to be low, it is possible that there were gravid females in the ice throughout the sampling period, but not collected on some occasions because of their low density. Continuous recruitment into the population is also indicated by the presence of young copepodites on all sampling dates. The location of modes in the size-frequency distributions of $C$. gracilis was similar from 15 May to the end of the study (Fig. 3). Fleeger (1979) gave size-frequency distributions for 3 harpacticoids from a salt marsh, each of which showed a pattern of constant peak locations for an extended period. He suggested that the stable population structures were brought about by continuous recruitment. C. gracilis has been found associated with macro-algae (Sars, 1918) and described as a phytophile (Ceccherelli, 1976). Most phytal harpacticoids reproduce continuously (Hicks, 1979), and C. gracilis, although a cyclopoid, may follow this pattern.

Harpacticus sp. did not appear to reproduce in the ice. Since the sampling period coincided with the annual ice algal bloom (Horner and Schrader, 1981), when food resources are highest, the lack of gravid females is surprising. Pre-copulatory clasping, which is typical in harpacticoids, occurred among individuals collected on 26 May and 2 June, and earlier in nonquantitative samples (J. Kern, pers. obs.). Fraser (1936) suggested that the clasping of females by adult males precedes spermatophore transfer. The reproductive cycle of Harpacticus sp. could be similar to that of $H$. uniremis. Jewett and Feder (1977) showed that $H$. uniremis at Port Valdez, Alaska, had a single distinct reproductive period. Males clasped females most often in April and into May, and gravid females began to appear approximately 9 mo later. Harpacticus sp. clasped around the same period, and gravid females did not appear before the end of our study.

No data for Harpacticus sp. are available from sediments during our study or the rest of the year, so it is not possible to describe the complete life-history of this organism. Mating evidently takes place in the ice since clasping was observed there. Inseminated females probably migrate to the bottom when the ice breaks up in late May or early June. It is not known whether copepods colonize the ice immediately after it reforms around October or later in the ice season. Low densities of diatoms are present in the ice from its formation and through the winter until around April (Clasby et al., 1972), so little food is presumably available at that time. No Harpacticus sp. adults were present in April and early May samples indicating either that colonization occurred shortly before by copepodites, or earlier by adult females. There are 2 possible explanations as to how females could colonize the ice during winter, in the near-absence of food, resulting in the population structure observed in our samples. First, they may produce cysts that could overwinter in the ice. Encystment has been shown to occur in the harpacticoid Heteropsyllus nunni, although it takes place prior to mating in this species (Coull and Grant, 1981). Second, it has been shown that certain harpacticoids have nauplii that undergo delayed development (Coull and Dudley, 1976), which could enable some offspring to survive under limited food conditions. Delayed naupliar development might explain the sudden influx of early copepodites on 2 June. Nauplii of benthic harpacticoids move by crawling (Hauspie and Polk, 1973), so colonization of the ice was probably not by nauplii unless they were advected to the ice from the benthos.

It is common for sex ratios to vary temporally in species of marine copepods (Moraitou-Apostolopoulou, 1972; Hicks, 1977). This was true for Harpacticus sp. and Cyclopina gracilis collected from the ice. There was a general trend in which the percentage of Harpacticus sp. females increased through the study. It appeared that the individuals of this species belonged to a single cohort; this suggests that males mature earlier than females. Males reached sizes at which they could be sexed before females, as indicated by the initial low percentage of females in the total sexable population. Earlier male development has been noted for Huntemania jadensis (Feller, 1980), H. uniremis (Jewett and Feder, 1977), and Tisbe furcata (Bergmans, 1981). It is not possible to discuss the relative development rates of $C$. gracilis males and females since recruitment to the population appeared to be continuous; however, Smyly (1961) reported that the males of 
Cyclops leukarti, a freshwater cyclopoid, mature earlier than females. Females predominated early in the study when the population density was low. This has been found to occur with other marine copepods (Moraitou-Apostolopoulou, 1972; Soyer, 1980).

It is not possible to describe the life-history of most species when sampling only during one season. Ice scraper samples were used to extend the sampling period as much as possible, even though these samples were taken outside of the study area. The size-frequency distributions of Harpacticus sp. and Cyclopina gracilis in these samples generally fit the trends exhibited in the cores. The only exception to this agreement is with the size-frequency distribution of $C$. gracilis on 14 April. The population appears to be older in this sample than in those collected on 24 April. Small-scale spatial heterogeneity in the population size-structures of benthic organisms has previously been observed (Curtis and Peterson, 1977), and may explain the apparent discrepancy in the size-frequency distributions between 14 April and 24 April. Sampling throughout the year, in the ice when the animals are there, and on the bottom when they are likely to inhabit the sediments, is required to describe the lifehistories of these organisms.

This study suggests that frequent sampling is required to observe changes in the population structure of meiofauna. Significant changes in the sizefrequency distributions for the 2 dominant ice copepods occurred on time scales of less than $1 \mathrm{wk}$, despite temperatures below $0^{\circ} \mathrm{C}$. Size-frequency distributions have been previously employed to study copepod life-histories (e. g. Lasker et al., 1970; Jewett and Feder, 1977; Fleeger, 1979; Soyer, 1980), but not sampling at intervals of less than $1 \mathrm{wk}$ as often done in this study. Many copepod species can undergo complete development in the lab, from hatch to hatch, in less than $30 \mathrm{~d}$ (Rosenfield and Coull, 1974), so frequent samples must be taken to observe the rapid changes in the populations.

In sum, unexpectedly high densities of several invertebrate taxa were present in seasonal ice of the Beaufort Sea in 1980. The high densities observed, and recent evidence showing that ice invertebrates are utilized by fish (Bradstreet and Cross, 1982), suggests that ice fauna may be more important in polar ecosystems than previously thought. Population characteristics of 2 ice-dwelling copepods, Cyclopina gracilis and Harpacticus sp., were not detectably different from those of benthic species studied elsewhere. It may be that no special adaptations or strategies are required to utilize the ephemeral ice environment. If this is true, it is surprising that not more species utilize the ice environment with its relatively concentrated food resources during spring bloom.
Acknowledgements. We thank R. E. Ruff, P. Scott, and K. Walters for assistance in the field. R. Poirot provided diving support. S. McNamara grammatically corrected an earlier version of this manuscript. S. Bell, G. Braun, P. Dawson, D. Gushee, E. W. Hogue, L. Miller, W. Pearcy, P. Scott, J. Shenker, J. M. Willis, and 2 anonymous reviewers made helpful comments on earlier versions of the manuscript. This study was funded through a grant to the junior author by the Bureau of Land Management through interagency agreement with the National Oceanic and Atmospheric Administration as part of the Outer Continental Shelf Environmental Assessment Program.

\section{LITERATURE CITED}

Andriashev, A. P. (1968). The problem of the life community associated with the Antarctic fast ice. In: Currie, R. I. (ed.) Symposium on Antarctic oceanography. Scott Polar Research Institute, Cambridge, pp. 147-155

Barnes, P. W., Reimnitz, E. (1975). Sedimentary processes on Arctic shelves off the northern coast of Alaska. In: Reed, $J$. C., Sater, J. E. (eds.) Proc. Sympos. Beaufort Sea Coast and Shelf Res. Arctic Institute, North America, Arlington, pp. 439-476

Barnett, P. R. O. (1970). The life cycles of two species of Platychelipus Brady (Harpacticoida) on an intertidal mudflat. Int. Revue ges. Hydrobiol. 55: 169-195

Bergmans, M. (1981). A demographic study of the life cycle of Tisbe furcata (Baird, 1837) (Copepoda: Harpacticoida). J. mar. biol. Ass. U. K. 61: 691-705

Bradstreet, M. W., Cross, W. E. (1982). Trophic relationships at high Arctic ice edges. Arctic 35: 1-12

Carey, A. G., Jr. (1981). The distribution, abundance, composition and variability of the western Beaufort Sea benthos Annual Report of Research Unit 6 to the Outer Continental Shelf Environmental Assessment Program. NOAA, Boulder, pp. 1-287

Carey, A. G., Jr., Montagna, P. A. (1982). Arctic sea ice faunal assemblage: first approach to description and source of the underice meiofauna. Mar. Ecol. Prog. Ser. 8: 1-8

Ceccherelli, V. U. (1976). Preliminary observations on zooplankton communities of the "Valli di Comacchio": the copepods. Archo Oceanogr. Limnol. 18: 411-424

Clasby, R. C., Horner, R., Alexander, V. (1972). An in situ method for measuring primary productivity of Arctic sea ice algae. J. Fish. Res. Bd Can. 30: 835-838

Coull, B. C., Bell, S. S. (1979). Perspectives of marine meiofaunal ecology. In: Livingston, R. J. (ed.) Ecological processes in coastal and marine systems. Plenum Publishing Corp., New York, pp. 189-216

Coull, B. C., Dudley, B. W. (1976). Delayed naupliar development of meiobenthic copepods. Biol. Bull, mar. biol. Lab., Woods Hole 150: $38-46$

Coull, B. C., Grant, J. (1981). Encystment discovered in a marine copepod. Science, N. Y. 212: 342-344

Cross, W. E. (1982). Under-ice biota at the Pond Inlet ice edge and in adjacent fast ice areas during spring. Arctic 35: $13-27$

Curtis, M. A., Peterson, G. H. (1977). Size-class heterogeneity within the spatial distributions of subarctic marine benthic populations. Astarte 10: 103-105

Feller, R. J. (1980). Quantitative cohort analysis of a sanddwelling meiobenthic harpacticoid copepod. Estuar. coast. mar. Sci. 2: 459-476

Fleeger, J. W. (1979). Population dynamics of three estuarine 
meiobenthic harpacticoids (Copepoda) in South Carolina. Mar. Biol. 52: 147-156

Fraser, J. H. (1936). The occurrence, ecology and life history of Tigriopus fulvus (Fischer). J. mar. biol. Ass. U. K. 20: $523-536$

Gerlach, S. A., Schrage, M. (1971). Life cycles in marine meiobenthos. Experiments at various temperatures with Monohystera disjuncta and Theristus pertenuis (Nematoda). Mar. Biol. 9: 274-280

Gerlach, S. A., Schrage, M. (1972). Life cycles at low temperatures in some free-living marine nematodes. Veröff. Inst. Meeresforsch. Bremerh. 14: 5-11

Hauspie, R., Polk, PH. (1973). Swimming behaviour patterns in certain benthic harpacticoids (Copepoda). Crustaceana 25: $95-103$

Hicks, G. R. F. (1977). Breeding activity of marine phytal harpacticoid copepods from Cook Strait. N. Z. J. mar Freshwat. Res. 11: 645-666

Hicks, G. R. F. (1979). Pattern and strategy in the reproductive cycles of benthic harpacticoid copepods. In: Naylor, E., Hartnoll, R. G. (eds.) Cyclic phenomena in marine plants and animals. Pergamon Press, Oxford and New York, pp. $139-147$

Horner, R. A. (1976). Sea ice organisms. Oceanogr. mar. biol. A. Rev. 14: 167-182

Horner, R. A. (1977). History and recent advances in the study of ice biota. In: Dunbar, M. J. (ed.) Polar oceans. Arctic Instit. North America, Calgary, Alberta, pp. 269-284

Horner, R. A., Schrader, G. C. (1981). Beaufort Sea plankton studies: winter-spring studies in Stefansson Sound and off Narwhal Island, Nov. 1978-June 1980. Final Report of Research Unit 359 to the Outer Continental Shelf Environmental Assessment Program. NOAA, Boulder, pp. 1-138

Jewett, S. C., Feder, H. M. (1977). Biology of the harpacticoid copepod, Harpacticus uniremis Kroyer on Dayville Flats, Port Valdez, Alaska. Ophelia 16: 111-129
Lasker, R., Wells, J. B. J., McIntyre, A. D. (1970). Growth, reproduction, respiration and carbon utilization of the sand-dwelling harpacticoid copepod, Asellopsis intermedia. J. mar, biol. A.ss. U. K. 50:147-160

Maykut, G. A., Grenfell, T. C. (1975). Th spectral distribution of light beneath first-year sea ice in the Arctic Ocean. Limnol. Oceanogr. 20: 554-563

McIntyre, A. D. (1969). Ecology of marine meiobenthos. Biol. Rev. 44: 245-290

Meguro, H., Ito, K., Fukushima, H. (1967). Ice flora (bottom type): a mechanism of primary production in polar seas and the growth of diatoms in sea ice. Arctic 20: 114-133

Moraitou-Apostolopoulou, M. (1972). Sex ratio in the pelagic copepods Temora stylifera Dana and Centropages typicus Kroyer. J. exp. mar. Biol. Ecol. 8: 83-87

Palmer, M. A. (1980). Variation in life-history patterns between intertidal and subtidal populations of the meiobenthic copepod Microarthridion littorale. Mar. Biol. 60: $159-165$

Rosenfield, D. C., Coull, B. C. (1974). Adult morphology and larval development of Paramphiascella fulvofasciatan. sp. (Copepoda, Harpacticoida). Cah. Biol. mar. 15: 295-317

Sars. G. O. (1918). Crustacea of Norway, Vol VI, Bergen Museum, Bergen

Scheibel, W. (1974). Submarine experiments on benthic colonization of sediments in the western Baltic Sea. II. Meiofauna. Mar. Biol. 28: 165-168

Soyer, J. (1980). Cycle biologique d'un copepode harpacticoide des vases terrigenes cotieres de Banyul-sur-Mer: Cletodes pusillus (Sars). Vie Milieu 30: 35-44

Smyly, W. J. P. (1961). The life-cycle of the freshwater copepod Cyclops leukarti Claus in Esthwaite Water. J. Anim. Ecol. 30: 153-169

Tate, M. W., Clelland, R. C. (1957). Nonparametric and shortcut statistics, Interstate Printers and Publishers, Inc., Dayville

This paper was presented by Professor G.-A. Paffenhöfer; it was accepted for printing on August 7, 1982 